\title{
Valorisation of ferric sewage sludge ashes: Potential as a phosphorus source
}

Guedes, Paula; Couto, Nazare; Ottosen, Lisbeth M.; Kirkelund, Gunvor Marie; Mateus, Eduardo; Ribeiro, Alexandra B.

Published in:

Waste Management

Link to article, DOI:

10.1016/j.wasman.2016.03.040

Publication date:

2016

Document Version

Peer reviewed version

Link back to DTU Orbit

Citation (APA):

Guedes, P., Couto, N., Ottosen, L. M., Kirkelund, G. M., Mateus, E., \& Ribeiro, A. B. (2016). Valorisation of ferric sewage sludge ashes: Potential as a phosphorus source. Waste Management, 52, 193-201.

https://doi.org/10.1016/j.wasman.2016.03.040

\section{General rights}

Copyright and moral rights for the publications made accessible in the public portal are retained by the authors and/or other copyright owners and it is a condition of accessing publications that users recognise and abide by the legal requirements associated with these rights.

- Users may download and print one copy of any publication from the public portal for the purpose of private study or research.

- You may not further distribute the material or use it for any profit-making activity or commercial gain

- You may freely distribute the URL identifying the publication in the public portal 


\section{Valorisation of ferric sewage sludge ashes: potential as a 2 phosphorus source}

3

4 Paula Guedes ${ }^{1,2}$, Nazaré Couto ${ }^{1,2^{*}}$, Lisbeth M. Ottosen ${ }^{2}$, Gunvor M. Kirkelund ${ }^{2}$, 5 Eduardo Mateus ${ }^{1}$, Alexandra B. Ribeiro ${ }^{1}$

$6{ }^{1}$ CENSE, Departamento de Ciências e Engenharia do Ambiente, Faculdade de Ciências e Tecnologia, Universidade $7 \quad$ Nova de Lisboa, Caparica, Portugal

$8 \quad{ }^{2}$ Department of Civil Engineering, Technical University of Denmark, Lyngby, Denmark

$9 *$ Corresponding author. Tel.: +351 212948300

10 E-mail address: md.couto@fct.unl.pt

\section{Abstract}

13 Sewage sludge ashes (SSA), although a waste, contain elements with socio-economic and environmental potential that can be recovered. This is the case of phosphorus $(\mathrm{P})$. SSA from two Danish incinerators were collected during two years and characterized. The sampling was done immediately after incineration (fresh SSA) or from an outdoor deposit (deposited SSA). Although morphology and mineral composition were similar, physico-chemical and metal concentration differences were found between incinerator plants and sampling periods. No differences were observed between deposited and fresh SSA, except for the parameters directly influenced by disposal conditioning (e.g. moisture content). All the SSAs had high concentrations of P (up to 16 wt. \%), but they all exceeded Danish EPA Cd and Ni thresholds for direct application at agricultural soil. Fresh and deposited SSA were acid washed aiming P extraction, achieving $50 \mathrm{~g} \mathrm{P} / \mathrm{kg}$ (approx. 37\% of total P), but metals were also co-extracted to the liquid phase. To avoid and/or minimize the metals pollution of the extracted $\mathrm{P}$, selective $\mathrm{P}$ recovery from the SSA was tested, using the electrodialytic (ED) process. ED laboratory cells, with 3 compartments (3c) and 2 compartments (2c), and two acid concentrations $\left(\mathrm{H}_{2} \mathrm{SO}_{4}, 0.08\right.$ $\mathrm{M}$ and $0.19 \mathrm{M}$ ) were used for 7 days. The most concentrated acid solution increased $\mathrm{P}$ solubilization. The 2c-cell combined with the higher acid concentration resulted in higher $\mathrm{P}$ recoveries, $125 \mathrm{~g}$ of $\mathrm{P} / \mathrm{kg}$ of SSA in the anolyte. The obtained results showed that the ED process is a valuable tool for the SSA valorisation as it promotes simultaneous $\mathrm{P}$ recovery and metals extraction from the SSA.

Keywords: Electrodialytic process, acid extraction, characterization, phosphorus, 
Incineration of sewage sludge ash (SSA) is a well-established technology (Werther and Ogada, 1999), being estimated that $300-400 \mathrm{~kg}$ of SSA are produced per ton of dried sewage sludge (Cyr et al., 2007). During the incineration process, organic contaminants and pathogens are destroyed, while achieving mass reduction, water evaporation and organic matter oxidation to $\mathrm{NO}_{\mathrm{x}}, \mathrm{SO}_{\mathrm{x}}$ and $\mathrm{CO}_{2}$. After the incineration in a fluidized bed furnace, exhaust gas fines are collected by electrostatic precipitators or bag filters (Donatello et al., 2010b). Incineration cost is about 210-310 euros per ton of dry solids but some controversy arises as this technique promotes potentially hazardous SSA (Smith et al., 2009). In fact, incineration can concentrate up to 13 times the amount of metals when compared to the ones reported in the original matrix (Donatello et al., 2010b; Ottosen et al., 2013).

The SSA are generally considered a waste material to be disposed into landfill (Donatello et al., 2010b), but they can also be reused as adsorbents (Pan et al., 2003), in geotechnical applications (Ferreira et al., 2003) or in construction materials (Al Sayed et al., 1995; Anderson et al., 2002; Lin et al., 2005), since SSA is not considered hazardous waste (Donatello et al., 2010b). Due to the P concentration, typically between 4 and 9\% (Biswas et al., 2009; Franz, 2008), fly SSA can be applied at agricultural land, if it complies with the established metal thresholds (e.g. Danish EPA, Miljøstyrelsen). However, as the bioavailability of phosphorus in the SSA is low the untreated ash may not be a suitable fertilizer (Krüger and Adam, 2015; Herzel et al., 2016).

The SSA can be treated aiming P extraction (Donatello et al., 2010a; Franz, 2008; Weigand et al., 2012) using different technologies, e.g. thermal (Adam et al., 2009; Mattenberger et al., 2008; Mattenberger et al., 2010; Vogel et al., 2010), wet treatment process (Petzet et al., 2011; Petzet et al., 2012; Stark et al., 2006) or electrodialytic (ED) separation (Ebbers et al. 2015; Guedes et al., 2014; Ottosen et al., 2014a). An experimental screening of ED P recovery and simultaneous metals removal has been conducted with a 3 compartment (3c) cell (Ebbers et al., 2015; Guedes et al., 2014; Ottosen et al., 2014a), Figure 1a (Jensen and Villumsen, 1995), and 2 compartment (2c) cell (Ebbers et al., 2015; Parés Viader et al., 2015), Figure 1b (Ottosen et al., 2014b). In the 3c cell, the possibility of P extraction from Al-rich and Fe-rich SSA was assessed using acid washing (Ottosen et al., 2013) and the ED process (Ottosen et al., 2014a). Phosphorus separation into the central compartment liquid and the anode compartment 
precipitated SSA. The combination of ED process in the 2c-cell and initial acidification of the stirred suspension with mineral acids showed to be more effective in dissolving $\mathrm{P}$, comparing to the 3c-cell. In the 2c-cell, removals up to 90\% (Parés Viader et al. 2015) and 96\% (Ebbers et al., 2015) were achieved in 7 days. A previous work reported phosphorus removals up to $70 \%$ have been achieved in the anode compartment of a $3 \mathrm{c}$ cell for deposited and fresh Fe-rich SSA of the 3c-cell using $0.08 \mathrm{M} \mathrm{H}_{2} \mathrm{SO}_{4}$ (Guedes et al., 2014). However, neither the 2c-cell setup nor the influence of acid concentration were evaluated.

This work had two main objectives: (i) to evaluate the major differences between SSA collected in different sampling periods, storage conditions and incinerator plants (Lynettefællesskabet and Avedøre Spildevandscenter, Copenhagen, Denmark), and (ii) to assess $\mathrm{P}$ recovery from recently collected (fresh) and deposited SSA. This last objective was tested with SSA, collected in the incinerator at Lynettefællesskabet, using a combined acid washing and ED treatment with a 3c and 2c-cell setups.

\section{Please insert Figure 1}

\section{Experimental}

\subsection{Sewage sludge ashes}

The SSA samples were collected after incineration by fluidized bed combustion at

Avedøre Spildevandscenter and Lynettefællesskabet wastewater treatment plants (WWTP), located in Copenhagen, Denmark. The plants treat waste water annually from 345,000 and 500,000 population equivalent, respectively, with no major industrial discharges, prevailing non-industrial wastewater. At both facilities $\mathrm{P}$ in the wastewater is precipitated in a Bio-P tank followed by addition of iron salt. After incineration of the sewage sludge, the SSA is collected in electrofilters and the ferric SSA is disposed of in separate landfills for SSA only. In total, 8 samples of SSA were collected. From Avedøre, two samplings (2012 and 2014) were made directly after the electrofilters (fresh). From Lynettefællesskabet, six samples (twice in 2012 and once in 2013) were collected from the electrofilters (fresh) and at the disposal site (deposited). The deposited SSA were collected from the top part of the SSA pile in an open air deposit, and the storage time is unknown. After sampling, the SSA was stored in closed plastic containers at room temperature until the experimental work was carried out. 
105 Characterization of the SSA and metals extraction were carried out with oven dried SSA

$106\left(105^{\circ} \mathrm{C}\right)$. For all characterization procedures five replicates of each type of SSA were 107 used. Water content of the SSA was calculated as weight loss at $105{ }^{\circ} \mathrm{C}$ for $24 \mathrm{~h}$. The $108 \mathrm{pH}$ was measured in a 1:2.5 (mass:volume) suspension in distilled water using a 109 Radiometer $\mathrm{pH}$ electrode. Loss on ignition (LOI) was determined in a muffle at $550{ }^{\circ} \mathrm{C}$ 110 for $30 \mathrm{~min}$. The concentrations of different elements were measured after pre-treatment 111 of the SSA in accordance to DS259 (2003), as $1.0 \mathrm{~g}$ of SSA and $20.0 \mathrm{~mL}(1: 1) \mathrm{HNO}_{3}$ 112 extracted at $200 \mathrm{kPa}, 120{ }^{\circ} \mathrm{C}$ for $30 \mathrm{~min}$ and then vacuum filtered through a $0.45 \mu \mathrm{m}$ 113 filter. Phosphorus, $\mathrm{Al}, \mathrm{Fe}, \mathrm{Zn}, \mathrm{Cu}, \mathrm{Pb}, \mathrm{Cr}, \mathrm{Cd}$ and $\mathrm{Ni}$ were measured by inductively 114 coupled plasma optical emission spectrometry (ICP-OES).

115 Morphology analysis was performed by scanning electron microscopy supported by 116 energy dispersive spectrometry (SEM-EDX), without pre-treatment of the SSA samples 117 (3 replicates were analysed for each SSA). The accelerating voltage of the SEM was 20$11825 \mathrm{kV}$ with large field detector (and X-ray cone). Different areas of the samples were 119 analysed by SEM and the element distribution was examined using EDX. SSA 120 mineralogy was studied by X-ray diffraction (XRD) for the identification of the major 121 crystalline phases. The instrument was a PANalytical X'Pert Pro operating at $45 \mathrm{kV}$ and $12240 \mathrm{~mA}$ applying $\mathrm{Cu} \mathrm{K \alpha}$ radiation with a $2 \Theta \mathrm{X}^{\prime}$ Celerator detector. The samples were 123 scanned in the range of 4-70 $2 \Theta$. The diffractograms were interpreted by using the 124 ICDD PDF-4 database for minerals.

\subsection{Relation between $\mathrm{pH}$ release of metals and $P$}

127 To determine the $\mathrm{pH}$ dependent extraction of $\mathrm{P}$ and metals, $10 \mathrm{~g}$ dried SSA were 128 suspended in $50 \mathrm{ml} \mathrm{HNO}_{3}$ of different concentrations $(0.00 ; 0.01 ; 0.05 ; 0.08 ; 0.10 ; 0.30$; $1290.50 ; 0.70$ and $1.0 \mathrm{M}$ ). The suspensions were placed at an agitating table for 7 days at 130 room temperature. At the end of the experiment, $\mathrm{pH}$ was measured and suspensions 131 were filtered by vacuum using $0.45 \mu \mathrm{m}$ filters and the concentrations determined by 132 ICP-OES. Each extraction was made in duplicate and reference samples were made 133 using distilled water with the same procedure. $\mathrm{pH}$ dependent extractions was carried out 134 for the Lynettefællesskabet SSA (2012, $1^{\text {st }}$ sampling). 
137 Two ED laboratory cells were used (Figure 1). The cells were made of plastic with an 138 internal diameter of $8 \mathrm{~cm}$, with a suspension compartment length of $10 \mathrm{~cm}$ and the 139 electrode compartment of $5 \mathrm{~cm}$. Electrode compartments were separated from the

140 suspension compartment by an anion-exchange membrane and/or a cation-exchange 141 membrane from Ionics (anion exchange membrane, AEM - AR204 SZRA B02249C 142 and cation exchange membrane, CEM - CR67 HUY N12116B). The electrodes were 143 platinum coated titanium from Permascand. A power supply (Hewlett Packard E3612A) 144 was used, maintaining a constant current of $50 \mathrm{~mA}$, corresponding to a current density 145 of $0.08 \mathrm{~mA} / \mathrm{cm}^{2}$, whereas in the $2 \mathrm{c}$-cell was of $0.10 \mathrm{~mA} / \mathrm{cm}^{2}$. The SSA was stirred in the 146 suspension compartment by a flexible plastic flab, coupled to a HETO motor, with a 147 rotation velocity rate of up to $1300 \mathrm{rpm}$. The SSA was suspended in $\mathrm{H}_{2} \mathrm{SO}_{4}$ at $0.19 \mathrm{M}$ in 148 the $3 \mathrm{c}$-cell and 0.08 and $0.19 \mathrm{M}$ for the $2 \mathrm{c}$-cell, in the ratio of 1:10 (mass:volume), and $149500 \mathrm{~mL}$ of $0.01 \mathrm{M} \mathrm{NaNO}_{3}$ was used as electrolyte, with $\mathrm{pH}$ adjusted to 2 with 1:1 $150 \mathrm{HNO}_{3}$. A total of six ED experiments with SSA from Lynettefællesskabet $\left(2012,1^{\text {st }}\right.$ 151 sampling), two experiments for each SSA sample (fresh and deposited) were carried out 152 for 7 days with different experimental conditions (Table 1).

153 During the experiments voltage, current, $\mathrm{pH}$ in the electrolytes and $\mathrm{pH}$ and conductivity 154 in the SSA suspension were measured. The $\mathrm{pH}$ of the electrolytes was manually 155 adjusted to $\mathrm{pH}$ between 1 and 2 with $1: 1 \mathrm{HNO}_{3}$ when necessary.

\section{Please insert Table 1}

159 At the beginning and at the end of each experiment, samples were taken from 160 electrolytes and from the suspension, for $\mathrm{P}$ and metal analyses. At the end of the experiments the SSA suspensions were drained through filter paper (grade 113, pore size $30 \mu \mathrm{m}$ ) before drying, to separate the solids from the liquid phase, and water content was measured. Membranes and cathode were soaked in $\mathrm{HNO}_{3}(1$ and $5 \mathrm{M}$, respectively) for 24 hours to release metals for further analysis. The SSA (three replicates), aqueous phases, electrolytes, membranes and cathode were analysed for $\mathrm{P}$ and metal contents, using the same ICP-OES.

167 The removal percentages were calculated by dividing the mass of element removed to different parts of the cell (electrodes, electrolyte solutions and membranes) by the sum of mass found in the different parts of the cell at the end of the experiment. 
172 Visual MINTEQ 3.1 was used to gain further insight into the formation of charged 173 phosphorus complexes which could be transported through the AEM and CEM. For the

174 calculations the chemical composition of the ash liquid solution in experiments after the

1757 days with elements present in $\mathrm{SSA}$ with $\mathrm{Fe}$ as $\mathrm{Fe}^{3+}$ or as $\mathrm{Fe}^{2+}$ was used. The $\mathrm{pH}$ was

176 fixed to the final experimental $\mathrm{pH}$ and temperature to $25^{\circ} \mathrm{C}$. The Ionic strength was 177 calculated in the program.

\subsection{Statistical analysis}

180 Physico-chemical characteristics, element concentrations in all fresh and deposited SSA were subjected to analysis of variance (ANOVA) and then compared by Tuckey multiple range test at $\mathrm{p}<0.05$. A Student t-test was used for comparison of SSA collected in the same incinerator plant.

\section{Results and Discussion}

\subsection{Chemical characterization of different SSA}

The characterization of fresh Avedøre SSA (2012 and 2014) and fresh/deposited Lynettefællesskabet SSA (2012 and 2013) is presented in Table 2.

189 Regarding physico-chemical characteristics, the changes in $\mathrm{pH}$ and conductivity did not

190 follow a specific tendency, differences being attributed to SSA heterogeneity 191 (wastewaters from different urban areas in Denmark but with no major industrial 192 discharges). The high difference in water content between deposited (up to 16\%) and 193 fresh $(\leq 0.1 \%)$ SSA was related to storage (e.g. air humidity, rain). The LOI was 194 generally low $(<0.9 \%)$, only increasing for one Lynettefællesskabet sample $(2.7 \%)$.

195 Both plant facilities have thus shown sufficient incineration conditions.

\section{Please insert Table 2}

199 The concentration of the different elements was in the same range in all studied SSA.

200 The P content was generally high in all SSA (between 7 and 16 wt. \%). Differences in P 201 are majorly attributed to population diet (Mihelcic et al., 2011), type of wastewater treatment plant system, and type of detergents used. In general, the $\mathrm{Zn}$ concentration was higher in Lynettefællesskabet 2012 SSA than in the other samples. In 2014,

204 Avedøre Spildevandscenter had higher concentrations of $\mathrm{Cu}$ and $\mathrm{Pb}$ than in 2012 or in 
Lynettefællesskabet. Again, these variations can be related to the characteristics of the area covered by the WWTP, which directly influence the heterogenous characteristics of the daily SS flows. Most of the studied Danish SSA were in accordance with reported literature ranges (Donatello et al., 2010a; Ebbers et al. 2015; Franz, 2008; Levlin et al., 2003; Ottosen et al., 2013) (also in Table 2, for comparison purposes), except for some samples with higher $\mathrm{Zn}, \mathrm{Cu}$ and $\mathrm{Pb}$ values or lower $\mathrm{Fe}$ and $\mathrm{Ni}$ concentrations. In this work, Cr levels were below all the concentrations reported in literature.

The Danish EPA has two set of limiting values for metals when spreading waste at agricultural land. The dry matter related concentrations (see Table 1) met the limiting values except for $\mathrm{Cd}(2.2-3.5 \mathrm{mg} / \mathrm{kg})$ and $\mathrm{Ni}(35-62 \mathrm{mg} / \mathrm{kg})$ for all $\mathrm{SSA}$, and $\mathrm{Pb}$ for one sampling period in Lynettefællesskabet and Avedøre (Table 2). As previously

216 discussed, the pre-treatment of the SSA would significantly improve the amount of P

217 bioavailable for agricultural application.

\subsection{Study of SSA from Lynettefællesskabet (2012)}

Deposited and fresh Lynettefællesskabet SSA from the first 2012 sampling (Table 2) were further analysed, including morphology, mineral composition and potential of acid washing to remove P. These SSA were chosen to deepen the comparison between fresh and deposited SSA.

\subsubsection{Morphology and mineral composition}

SEM analysis show that the SSA particles generally had irregular shaped (Figure 2) and no major differences were found between fresh and deposited samples. Additionally, $\mathrm{SEM} / \mathrm{EDX}$ analysis revealed that $\mathrm{O}, \mathrm{P}, \mathrm{Fe}, \mathrm{Al}, \mathrm{K}, \mathrm{Na}, \mathrm{Mg}, \mathrm{Si}, \mathrm{S}$, and $\mathrm{Ca}$ were distributed all over the particle surfaces in both SSA.

\section{Please insert Figure 2}

The mineralogy of fly SSA generally represents an assemblage of crystalline and amorphous phases (Bayuseno and Schmahl, 2011). The major mineral phases identified by XRD are presented in Figure 3 and show differences between deposited and fresh SSA. Silicon oxide in the form of quartz $\left(\mathrm{SiO}_{2}\right)$ was identified in both SSA, agreeing with published data for other SSA (Cyr et al., 2007) where Si is likely to be present in its crystalline or amorphous phase. Phosphates on both SSA were indicated as calcium 
239 phosphates, but the only chemical formula clearly identified was as whitlockite

$240\left[\mathrm{Ca}_{9}(\mathrm{MgFe})\left(\mathrm{PO}_{4}\right)_{6} \mathrm{PO}_{3} \mathrm{OH}\right]$. Hematite $\left(\mathrm{Fe}_{2} \mathrm{O}_{3}\right)$ was also identified, being the iron oxide a

241 consequence of SS incineration $\left(800-900^{\circ} \mathrm{C}\right)$ in excess air which promotes the existence

242 of metals as oxides (Donatello et al., 2010b).

\section{Please insert Figure 3}

There was $\mathrm{CaSO}_{4}$ in both samples, however difficult to completely identify. In the fresh sample, it is likely present as anhydrite $\left(\mathrm{CaSO}_{4}\right)$ and in the deposited, it was not clear, although not anhydrite nor gypsum $\left(\mathrm{CaSO}_{4} \cdot 2 \mathrm{H}_{2} \mathrm{O}\right)$. However, anhydrite can be present in SSA when they are fresh but as a result of "hydration" of the SSA, gypsum may start to form (Bayuseno and Schmahl, 2011), though this was not confirmed by XRD in the present work. In SEM/EDX a $\mathrm{S}$ rich region was observed and can belong to i) an amorphous $\mathrm{CaSO}_{4}$ or ii) $\mathrm{Na}_{2} \mathrm{SO}_{4} / \mathrm{K}_{2} \mathrm{SO}_{4} / \mathrm{NaKSO}_{4}$ condensed on this Ca-rich particle. The amorphous phase in other SSAs is between 40-74\% (Cyr et al., 2007). In this case, from XRD patterns of fresh and deposited SSA samples it can be inferred that some amorphous phases are present due to the slight hump between $2 \theta$ of 10 and $30^{\circ}$ but the material is not prevalently amorphous.

257 A semi-quantitative method, Reference Intensity Ratio (RIR), based on the diffraction intensity of the strongest peak of a given phase in comparison with corundum, was used to indicate the relative mineral mass fractions in the two SSA. The RIR method indicated that the mass distribution of the major crystalline phases in both SSA were as following: calcium phosphate and quartz > iron oxide and calcium sulphate.

\subsubsection{Acid washing of SSA}

264 The percentage of $\mathrm{P}$ extracted from the SSA as a function of $\mathrm{pH}$ is shown in Figure 4. 265 Storage did not affect the extent of $\mathrm{P}$ extraction even at the strongest concentration, 1.0 $266 \mathrm{M}$, where more than $50 \mathrm{~g} / \mathrm{kg}$ were extracted. This $40 \%$ of total $\mathrm{P}$ mobilization is in accordance with the average percentage reported in other works, for the same $\mathrm{pH}$

268 (Ottosen et al., 2013). A pH decrease, other L/S ratios or extracting agents could have increase the total amount of mobilized P (Ottosen et al., 2013).

270 Regarding storage, the release of a specific element as a function of $\mathrm{pH}$ is very similar

271 for fresh and deposited SSA, except for a slight variation of $\mathrm{Cd}$ at $\mathrm{pH}$ between 2 and 3.

272 The major mineralogy of the material and the phases controlling the solubility of major 
trace elements (as suggested by the results of mineralogy test) were also not affected,

274 neither the amount of elements extracted. Instead, extraction is mainly correlated with $275 \mathrm{pH}$ changes, particularly at low $\mathrm{pH}$ values. At low $\mathrm{pH}$ values the solubilized percentages were: $\mathrm{Zn} \mathrm{65 \% ,} \mathrm{Cu}$ approx. 55\%, and less than 33\% Ni and Al (Figure 4). Iron was

277 bound strongly in both SSA, and even at the lowest $\mathrm{pH}$, less than $2 \%$ was solubilized.

278 This is in accordance to what was expected as $\mathrm{Fe}_{2} \mathrm{O}_{3}$, which is insoluble in acid 279 (Donatello et al., 2010b), was identified in larger quantities in both SSA. The XRD 280 investigation also showed the presence of $\mathrm{Ca}_{9}(\mathrm{MgFe})\left(\mathrm{PO}_{4}\right)_{6} \mathrm{PO}_{3} \mathrm{OH}$ in the SSA. But, 281 since at low $\mathrm{pH}$, only a small amount of Fe was extracted in contrast to more than $35 \%$ of $\mathrm{P}$ in both samples (Figure 4) these two elements may have not been associated in the $\mathrm{SSA}$, even though $\mathrm{Fe}$ was originally used for precipitation of $\mathrm{P}$ during the wastewater treatment. As metals mobilization started approximately at the same $\mathrm{pH}$ than $\mathrm{P}$ mobilization, the obtained acidic liquid solution was a mixture between $\mathrm{P}$ and metals, and a further separation step is needed.

\section{Please insert Figure 4}

\subsubsection{Electrodialytic treatment}

\subsubsection{Mass balance}

Mass balance of an element was defined as the relation between the sum of mass found in the different parts of the cell at the end of the experiment and the initial mass calculated on basis of the mean initial concentration. The mass balances for the elements presented high variability for all the experiments. An inhomogeneous distribution of metals in the ash and, consequently, imperfect mass balances are expected when working with these type of samples. Finally, even though careful handling of all samples the precipitation of insoluble compounds may occur in e.g. setup tubing. Mass balance in the different experiments varied between 80-120\% with no

$300 \quad$ linear tendency.

\subsubsection{Electrodialytic P-separation}

303 Table 3 shows the initial conditions and the changes in $\mathrm{pH}$, conductivity and mass loss

304 after the ED experiments. Before the experiment the SSA was suspended in sulphuric 305 acid $(0.08$ and $0.19 \mathrm{M})$ aiming to convert the precipitated and adsorbed $\mathrm{P}$ into mobile 
306 ionic forms able to electromigrate during the ED treatments. The initial $\mathrm{pH}$ in the

307 central cell compartment varied between 1.0 and 2.6 for the SSA (Table 2). During the

308 ED experiments, $\mathrm{pH}$ in the SSA compartment slightly decreased in the $3 \mathrm{c}$-cell and

309 continued to decrease in the 2c-cell due to the generation of $\mathrm{H}^{+}$in the anode

310 compartment. Water splitting at the AEM may have also contributed for the

311 acidification. The dissolution of ash particles during the ED treatment results in a mass

312 loss that can be quite significant (Guedes et al., 2014; Ottosen et al., 2006) as it can be

313 seen in Table 3. In the 2c-cell experiments there was a conductivity increase at the end

314 of the experiments. This is due to the electrolysis at the anode and solubilisation of SSA

315 ions that are not transported out of the suspension as fast as produced. In the $3 c$-cell the

316 solubilized ions from the SSA suspension are migrating either to the anode or cathode

317 compartments. Consequently, the central compartment is being depleted from ions,

318 which decreases the conductivity of the suspension.

\section{$320 \quad$ Please insert Table 3}

322 In the ED cells, the released metals are expected to be found as positively charged species whereas the solubilised $\mathrm{P}$ is more likely to be found in negatively charged or neutral species at acidic $\mathrm{pH}\left(\mathrm{H}_{3} \mathrm{PO}_{4}, \mathrm{H}_{2} \mathrm{PO}_{4}{ }^{-}\right)$, except for $\mathrm{Al}-\mathrm{P}$, Ca-P and $\mathrm{Fe}-\mathrm{P}$ complexes formation. In the $3 \mathrm{c}$-cell the main objective is to dissolve and mobilize the $\mathrm{P}$ from the SSA suspension (central compartment) to the anode compartment and the metals to the cathode compartment. In the $2 \mathrm{c}$-cell the aim is to dissolve $\mathrm{P}$ and metals from the SSA keeping P in the suspension (anolyte) whereas the metals are removed into the cathode compartment. Afterwards the ED treatment using the 2c-cell, the suspension (anolyte) is filtered, being the P rich filtrate cleaned from ash particles.

In this study, a more concentrated $\mathrm{H}_{2} \mathrm{SO}_{4}$ solution was used in the $3 \mathrm{c}$-cell compared to the previous work where $0.08 \mathrm{M}$ solution was used (Guedes et al., 2014). The increase in the acid concentration improved P solubilization by 17\% (experiments F-3-0.19 and D-3-0.19, Figure 5). In total between 24.9 and $29.4 \%$ of $P$ were removed to the anolyte of the 3c-cell, mainly as $\mathrm{H}_{2} \mathrm{PO}_{4}^{-}$(Table 4), whereas in the previous work 17.9 and $18.8 \%$ were removed to the anolyte after 7 days (Guedes et al., 2014).

\section{Please insert Figure 5}


340 When the 2c-cell with $0.08 \mathrm{M}^{\circ} \mathrm{H}_{2} \mathrm{SO}_{4}$ was used $91 \%$ of $\mathrm{P}$ for F-2-0.08 and $67 \%$ for

341 D-2-0.08 were solubilized. From these, 14 and 11\% of P (F-2-0.08 and D-2-0.08, 342 respectively) electromigrated to the cathode compartment, probably due to the 343 complexation with $\mathrm{Al}, \mathrm{Fe}$ and $\mathrm{Ca}$ forming positively charged species like $\mathrm{AlHPO}_{4}{ }^{+}$, $344 \mathrm{CaH}_{2} \mathrm{PO}_{4}{ }^{+}$and $\mathrm{FeH}_{2} \mathrm{PO}_{4}{ }^{2+}$ (Table 4). At the end, the anolyte solution still contained $34577 \%$ of $\mathrm{P}$ in F-2-0.08 and 56\% in D-2-0.08 (Figure 5) being mainly present as $\mathrm{H}_{3} \mathrm{PO}_{4}$ 346 and $\mathrm{H}_{2} \mathrm{PO}_{4}{ }^{-}$(Table 4). In the acid washing test, this difference in $\mathrm{P}$ solubilization was 347 not observed. One hypotheses is that deposited SSA sample used in the experiment D348 2-0.08 may have contained more acid-insoluble P-complexes (samples heterogeneity) 349 influencing the results. Still, in these two experiments, the type of SSA influenced the 350 total P solubilization by the different setups and, consequently, the amount collected in 351 the anolyte solution. In this case, the best option may be to use ash collected 352 immediately after incineration. The increase in the acid concentration in the 2c-cell set353 up resulted in higher P solubilization from the SSA, approx. 99\% in both cases. From these, 93 and $97 \%$ in the F-2-0.19 and D-2-0.19, respectively, remained in the anolyte as $\mathrm{H}_{3} \mathrm{PO}_{4}$ and $\mathrm{H}_{2} \mathrm{PO}_{4}^{-}$(Table 4). Only 7\% in F-2-0.19 and 2\% in D-2-0.19 electromigrated toward the cathode compartment mainly as $\mathrm{Al}, \mathrm{Ca}$, and $\mathrm{Fe}$ complexes $\left(\mathrm{AlHPO}_{4}{ }^{+}, \mathrm{Al}_{2} \mathrm{PO}_{4}{ }^{+3}, \mathrm{CaH}_{2} \mathrm{PO}_{4}{ }^{+}, \mathrm{FeH}_{2} \mathrm{PO}_{4}{ }^{2+}\right.$ and $\mathrm{FeHPO}_{4}{ }^{+}$, Table 4). In terms of metals, generally, higher removals were achieved when $0.19 \mathrm{M}$ of $\mathrm{H}_{2} \mathrm{SO}_{4}$ was used compared to the use of $0.08 \mathrm{M}$, independently of the cell design (3c-cell or 2ccompartment). The metals solubilization after the 7 days of experiment were:

- $\mathrm{Fe}(9 \%)<\mathrm{Pb}(14 \%)<\mathrm{Cr}(16 \%)=\mathrm{Ni}<\mathrm{Zn}(56 \%)<\mathrm{Al}(57 \%)<\mathrm{Cu}(69 \%)<\mathrm{Cd}$ (82\%) for F-3-0.19

- $\mathrm{Pb}(10 \%)<\mathrm{Fe}(12 \%)<\mathrm{Cr}(20 \%)<\mathrm{Ni}(36 \%)<\mathrm{Al}(44 \%)<\mathrm{Zn}(73 \%)<\mathrm{Cu}$ $(76 \%)<\mathrm{Cd}(82 \%)$ for D-3-0.19

- $\mathrm{Pb}(7 \%)<\mathrm{Fe}(10 \%)<\mathrm{Cr}(11 \%)<\mathrm{Ni}(16 \%)<\mathrm{Cd}(18 \%)<\mathrm{Al}(53 \%)<\mathrm{Cu}$ $(55 \%)<\mathrm{Zn}(64 \%)$ for $\mathrm{F}-2-0.08$

- $\mathrm{Pb}(9 \%)<\mathrm{Fe}(12 \%)=\mathrm{Cr}<\mathrm{Ni}(17 \%)<\mathrm{Cd}(23 \%)<\mathrm{Al}(42 \%)<\mathrm{Cu}(44 \%)<\mathrm{Zn}$ (51\%) for D-2-0.08

- $\mathrm{Fe}(6 \%)<\mathrm{Cr}(10 \%)<\mathrm{Pb}(12 \%)<\mathrm{Ni}(13 \%)<\mathrm{Cd}(23 \%)<\mathrm{Al}(53 \%)=\mathrm{Zn}<\mathrm{Cu}$ $(69 \%)$ for F-2-0.19

- $\mathrm{Fe}(8 \%)<\mathrm{Pb}(14 \%)<\mathrm{Cr}(16 \%)<\mathrm{Ni}(18 \%)<\mathrm{Cd}(27 \%)<\mathrm{Zn}(51 \%)<\mathrm{Al}$ $(61 \%)<\mathrm{Cu}(64 \%)$ for D-2-0.19 
373 The exception was $\mathrm{Cd}$ which solubilization was higher in the $3 \mathrm{c}$-cell, $82 \%$ in both 374 experiments (F-3-0.19 and D-3-0.19) contrasting to the 23 and $27 \%$ in the F-2-0.19 and 375 D-2-0.19, respectively. In the 2c-cell experiments, between 73-82\% of Cd remained in 376 the ash whereas in the $3 \mathrm{c}$-cell the value was $18 \%$. Although unclear, a possible 377 explanation is that the reactions that occurred in the anode end, where the SSA is 378 placed, might have affected the Cd solubilization (e.g. precipitation) and this should be

379 further investigated. Still, higher solubilization values for Cd (89\%) were obtained by 380 Ebbers et al. (2015) using a 2c-cell with $0.19 \mathrm{M}$ of $\mathrm{H}_{2} \mathrm{SO}_{4}$.

$381 \mathrm{As} \mathrm{Fe}$ and $\mathrm{Pb}$ are tightly bounded to more insoluble ashes particles (Ottosen et al., 382 2014a) neither the increase in the acid concentration nor the change in the cell design 383 improved their removals.

384 Comparing to the previous work (Guedes et al., 2014) generally, higher percentages 385 were solubilized from the SSA in these experiments (F-3-0.19 and D-3-0.19) due to the 386 increased acid concentration, $0.19 \mathrm{M}$. Between more 3\% (Fe in the fresh SSA) and 36\% 387 (Cd in the deposited SSA) were solubilized from the SSA comparing to the results obtained with $0.08 \mathrm{M}$ (Guedes et al., 2014). No differences were found for $\mathrm{Al}$ in the deposited SSA (D-3-0.19) and $\mathrm{Cr}$ and $\mathrm{Cu}$ in the fresh SSA (F-3-0.19).

\section{Please insert Table 4}

\subsubsection{Techniques comparison}

394 At the end of all ED experiments $\mathrm{pH}$ was between 1.9 and 1.2. Through comparison to acid washing, it was expected that at least $35 \%$ of $\mathrm{P}$ had been solubilized from the SSA in the ED cells (Figure 4) staying in the anode compartment in the 2c-cell or electromigrating to anode compartment in the case of the 3c-cell. In all cases, the amount of $\mathrm{P}$ solubilized was higher in the ED cell (generally higher than $80 \%$, except in D-2-0.08 that was 67\%) than in the acid washing. This may be attributed to four factors: (i) the use of sulphuric acid in the ED treatment, instead of the nitric acid used in the acid washing; (ii) the combination of an increased solubilisation of $\mathrm{P}$ compounds, due to equilibrium displacement by $\mathrm{Al}, \mathrm{Ca}$ and $\mathrm{Fe}$ cations migration into the catholyte (Parés Viader et al., 2015); (iii) a higher liquid-to-solid ratio (L/S) in the ED remediation $(\mathrm{L} / \mathrm{S}=10)$ than in the acid extraction experiments $(\mathrm{L} / \mathrm{S}=5)$; and (iv) the continuous 
advantage of the ED process comparing to acid washing is the simultaneous extraction and separation of $\mathrm{P}$ from the other element in the ash, namely the metals.

Between cell designs, the use of a 2c-cell setup increased overall efficiency of $\mathrm{P}$ recovery after 7 days of experiment, under the conditions here tested. Although the applied current was the same $(50 \mathrm{~mA})$ the corresponding current density was different $\left(0.08 \mathrm{~mA} / \mathrm{cm}^{2}\right.$ in the $3 \mathrm{c}$-cell vs $0.10 \mathrm{~mA} / \mathrm{cm}^{2}$ in the $2 \mathrm{c}$-cell) which may have influenced the results. Also, $\mathrm{P}$ dissolution seems to be faster and more complete in the 2c-cell experiments than in the $3 \mathrm{c}$-cell, possibly due to the faster formation of $\mathrm{H}^{+}$ions due to water electrolysis. Another important factor is that, at the end of experiments, the $\mathrm{P}$ that stays in the suspension of the anode compartment (anolyte) in the 2c-cell (either as uncharged species or anions) is accounted as recovered whereas in the 3c-cell the amount of $\mathrm{P}$ that stays in the central compartment liquid (as neutral species) is not considered recovered. At the end, and though the amount of $\mathrm{P}$ solubilized in the $3 \mathrm{c}$-cell and 2c-cell using $0.19 \mathrm{M}$ of $\mathrm{H}_{2} \mathrm{SO}_{4}$ was very similar (approx. 92\% and 99\%, respectively), the $\mathrm{P}$ recovered was only $25-29 \%$ in the 3c-cell contrasting to the $93-97 \%$ in the 2c-cell. Still, in the 2c-cell set-up, the $\mathrm{P}$ was not completely separated from the metals as it can be seen in Table 5 (for example, 32\% of Al for F-2-0.19 and 45\% for D2-0.19 are still in the anolyte). From the total amount of elements analysed, the anolyte solution of D-2-0.19 was constituted by $90 \%$ of P and $10 \%$ of metals, whereas F-2-0.19 anolyte contained $93 \%$ of $\mathrm{P}$ and the remaining $8 \%$ were metals.

\section{Please insert Table 5}

\section{Conclusions}

The SSA from Avedøre and Lynettefællesskabet incinerator plants showed no large differences between their chemical characteristics, except for those related with SSA heterogeneity. Additionally, samples collected at different stages (fresh and deposited) at the same incineration plant showed no trending differences in metal content and physico-chemical parameters. The exception was the moisture content, which was directly related with the disposal conditions.

All the SSA exceeded Danish EPA Cd and Ni thresholds regarding agriculture application. Their high P concentration (up to $16 \mathrm{wt}$. \%) justifies the need of P recovery. More than $50 \mathrm{~g}$ of $\mathrm{P} / \mathrm{kg}$ was extracted from fresh and deposited Lynettefællesskabet SSA (2012) by acid washing, together with a high amount of metals. 
The ED process proved to be a viable option for simultaneous extraction and separation of metals and $\mathrm{P}$ thus promoting the valorization of the SSA. The use of a 2c-cell to solubilize and separate $\mathrm{P}$ from the metals seems to be the best option with the best results being achieved when $0.19 \mathrm{M}$ of $\mathrm{H}_{2} \mathrm{SO}_{4}$ were used (up to $99 \%$ of $\mathrm{P}$ solubilization). In total, approx. $125 \mathrm{~g}$ of $\mathrm{P} / \mathrm{kg}$ of SSA were recovered in the anolytes showing that the SSA are valuable P sources. However, the optimization of the ED conditions, current and duration, are still needed aiming at decreasing energy costs.

Although more tests are needed, the type of ash used in the process may influence $\mathrm{P}$ recovery, and it needs to be taken into account. In this study, the SSA collected after the incineration allowed to recover more $24 \%$ of $\mathrm{P}$ than the use of the SSA collected from the deposit, when the $2 \mathrm{c}$-cell with $0.08 \mathrm{M}$ of sulfuric acid was used.

\section{Acknowledgements}

Authors would like to thank Ebba C. Schnell, Sabrina Madsen, Christina W. Dufke for laboratorial support and analysis, as well as Lynettefællesskabet for providing the SSA samples. Morten Reiff, Morten G. Meldgaard, Asger B. Carlsen, Søren R. Petersen, Christine Rem, Jeppe Søbye Andreasen, Leander Jørgensen, Gonca Kurt, Liv Rosenmai and Sabine Svendsen are thanked for all their experimental and analytical work. Cátia Magro is acknowledged for statistical analysis. Financial support for the work was provided by projects FP7-PEOPLE2010-IRSES-269289-ELECTROACROSS and PTDC/ECM/111860/2009. N. Couto also thanks

Fundação para a Ciência e a Tecnologia for her Post-Doc fellowship (SFRH/BPD/81122/2011).

462

\section{References}

465

466

Adam, C., Peplinski, B., Michaelis, M., Kley, G., Simon, F.G., 2009. Thermochemical treatment of sewage sludge ashes for phosphorus recovery. Waste Management 29, 1122-1128.

Al Sayed, M.H., Madany, I.M., Buali, A.R.M., 1995. Use of sewage sludge ash in asphaltic paving mixes in hot regions. Construction and Building Materials 9, 1923.

Anderson, M., Elliott, M., Hickson, C., 2002. Factory-scale proving trials using combined mixtures of three by-product wastes (including incinerated sewage sludge ash) in clay building bricks. Journal of Chemical Technology \& Biotechnology 77, 345-351.

Bayuseno, A.P., Schmahl, W.W., 2011. Characterization of MSWI fly ash through mineralogy and water extraction. Resources, Conservation and Recycling 55, 524534.

Biswas, B.K., Inoue, K., Harada, H., Ohto, K., Kawakita, H., 2009. Leaching of phosphorus from incinerated sewage sludge ash by means of acid extraction 
followed by adsorption on orange waste gel. Journal of Environmental Sciences 21, 1753-1760.

Cyr, M., Coutand, M., Clastres, P., 2007. Technological and environmental behavior of sewage sludge ash (SSA) in cement-based materials. Cement and Concrete Research 37, 1278-1289.

Donatello, S., Tong, D., Cheeseman, C.R., 2010a. Production of technical grade phosphoric acid from incinerator sewage sludge ash (ISSA). Waste Management 30, 1634-1642.

Donatello, S., Tyrer, M., Cheeseman, C.R., 2010b. EU landfill waste acceptance criteria and EU Hazardous Waste Directive compliance testing of incinerated sewage sludge ash. Waste Management 30, 63-71.

DS259, 2003. Determination of metals in water, sludge and sediments - General guidelines for determination by atomic absorption spectrophotometry in flame, Dansk Standardiseringsråd.

Ebbers, B., Ottosen, L.M., Jensen, P.E., 2015. Comparison of two different electrodialytic cells for separation of phosphorus and heavy metals from sewage sludge ash. Chemosphere 125, 122-129.

Ferreira, C., Ribeiro, A., Ottosen, L., 2003. Possible applications for municipal solid waste fly ash. Journal of Hazardous Materials 96, 201-216.

Franz, M., 2008. Phosphate fertilizer from sewage sludge ash (SSA). Waste Management 28, 1809-1818.

Guedes, P., Couto, N., Ottosen, L., Ribeiro, A., 2014. Phosphorus recovery from sewage sludge ash through an electrodialytic process. Waste Management 34, 886892.

Herzel, H., Krüger, O., Hermann, L., Adam, C., 2016. Sewage sludge ash - A promising secondary phosphorus source for fertilizer production. Science of The Total Environment 542, Part B, 1136-1143.

Jensen, J.B., Villumsen, A., 1995. Method and apparatus for the decontamination of products containing heavy metal, PCT/DK95/00209.

Krüger, O., Adam, C., 2015. Recovery potential of German sewage sludge ash. Waste Management 45, 400-406.

Levlin, E., Löwén, M., Stark, K., 2003. Phosphorus recovery from sludge incineration ash and supercritical water oxidation residues with use of acids and bases. Report No. 11. Integration and Optimization of Urban Sanitation Systems, Wisla.

Lin, D.-F., Luo, H.-L., Sheen, Y.-N., 2005. Glazed Tiles Manufactured from Incinerated Sewage Sludge Ash and Clay. Journal of the Air \& Waste Management Association 55, 163-172.

Mattenberger, H., Fraissler, G., Brunner, T., Herk, P., Hermann, L., Obernberger, I., 2008. Sewage sludge ash to phosphorus fertiliser: Variables influencing heavy metal removal during thermochemical treatment. Waste Management 28, 27092722.

Mattenberger, H., Fraissler, G., Jöller, M., Brunner, T., Obernberger, I., Herk, P., Hermann, L., 2010. Sewage sludge ash to phosphorus fertiliser (II): Influences of ash and granulate type on heavy metal removal. Waste Management 30, 1622-1633.

Mihelcic, J.R., Fry, L.M., Shaw, R., 2011. Global potential of phosphorus recovery from human urine and feces. Chemosphere 84, 832-839.

Ottosen, L.M., Jensen, P.E., Kirkelund, G.M., 2014a. Electrodialytic Separation of Phosphorus and Heavy Metals from Two Types of Sewage Sludge Ash. Separation Science and Technology 49, 1910-1920. 
Ottosen, L.M., Jensen, P.E., Kirkelund, G.M., Ebbers, B., 2014b. Electrodialytic recovery and purification of phosphorous from sewage sludge ash, sewage sludge and wastewater, PCT/EP2014/068956.

Ottosen, L.M., Kirkelund, G.M., Jensen, P.E., 2013. Extracting phosphorous from incinerated sewage sludge ash rich in iron or aluminum. Chemosphere 91, 963-969.

Ottosen, L.M., Lima, A.T., Pedersen, A.J., Ribeiro, A.B., 2006. Electrodialytic extraction of $\mathrm{Cu}, \mathrm{Pb}$ and $\mathrm{Cl}$ from municipal solid waste incineration fly ash suspended in water. Journal of Chemical Technology \& Biotechnology 81, 553559.

Pan, S.-C., Lin, C.-C., Tseng, D.-H., 2003. Reusing sewage sludge ash as adsorbent for copper removal from wastewater. Resources, Conservation and Recycling 39, 7990.

Parés Viader, R., Jensen, P.E., Ottosen, L.M., Ahrenfeldt, J., Hauggaard-Nielsen, H., 2015. Electrodialytic extraction of phosphorus from ash of low-temperature gasification of sewage sludge. Electrochimica Acta 181, 100-108.

Petzet, S., Peplinski, B., Bodkhe, S.Y., Cornel, P., 2011. Recovery of phosphorus and aluminium from sewage sludge ash by a new wet chemical elution process (SESAL-Phos-recovery process). Water Science \& Technology 64, 693-699.

Petzet, S., Peplinski, B., Cornel, P., 2012. On wet chemical phosphorus recovery from sewage sludge ash by acidic or alkaline leaching and an optimized combination of both. Water Research 46, 3769-3780.

Smith, K.M., Fowler, G.D., Pullket, S., Graham, N.J.D., 2009. Sewage sludge-based adsorbents: A review of their production, properties and use in water treatment applications. Water Research 43, 2569-2594.

Stark, K., Plaza, E., Hultman, B., 2006. Phosphorus release from ash, dried sludge and sludge residue from supercritical water oxidation by acid or base. Chemosphere 62 , 827-832.

Vogel, C., Adam, C., Peplinski, B., Wellendorf, S., 2010. Chemical reactions during the preparation of $\mathrm{P}$ and NPK fertilizers from thermochemically treated sewage sludge ashes. Soil Science \& Plant Nutrition 56, 627-635.

Weigand, H., Bertau, M., Hübner, W., Bohndick, F., Bruckert, A., 2012. RecoPhos: Full-scale fertilizer production from sewage sludge ash. Waste Management.

Werther, J., Ogada, T., 1999. Sewage sludge combustion. Progress in Energy and Combustion Science 25, 55-116. 


\section{Highlights}

- Sewage sludge ashes fresh and deposited were studied aiming phosphorus recovery

- Ashes physico-chemical differences depended on incinerator plant and sampling date

- Phosphorus solution after acid wash contained high amount of heavy metals

- The 2 compartment ED-cell improved phosphorus extraction and recovery

- A cleaner phosphorus solution was obtained after ED 


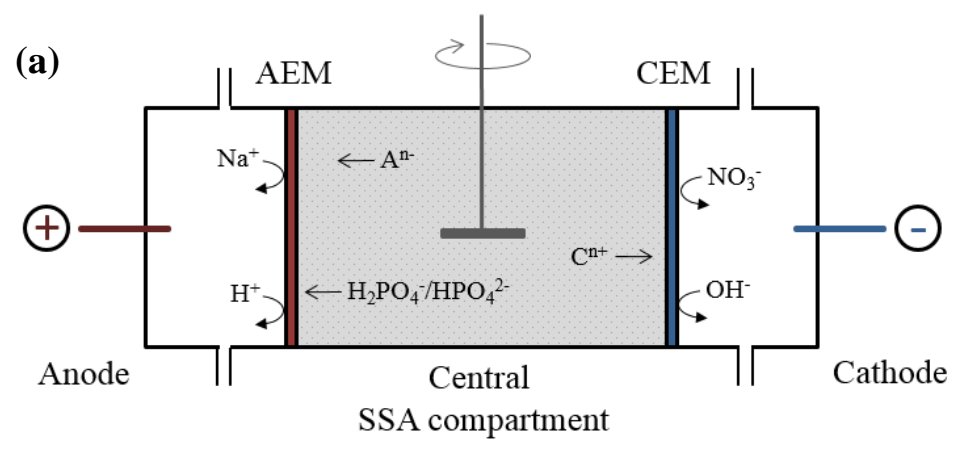

(b)

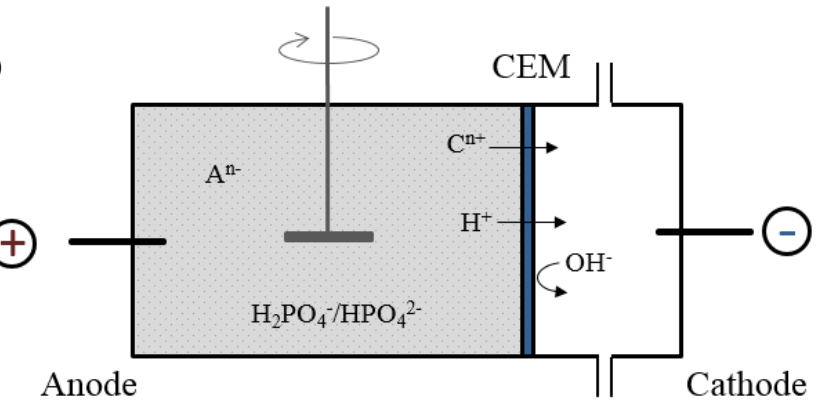

SSA compartment

Figure 1. Schematic view of (a) 3-compartment and (b) 2-compartment electrodialytic laboratory cell. (CEM: cation exchange membrane; AEM: anion exchange membrane) 
Figure 2

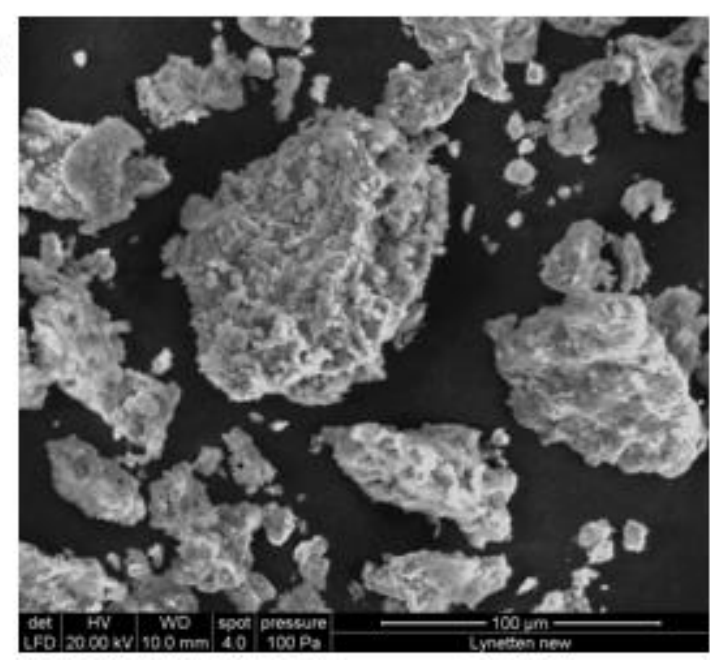

Figure 2

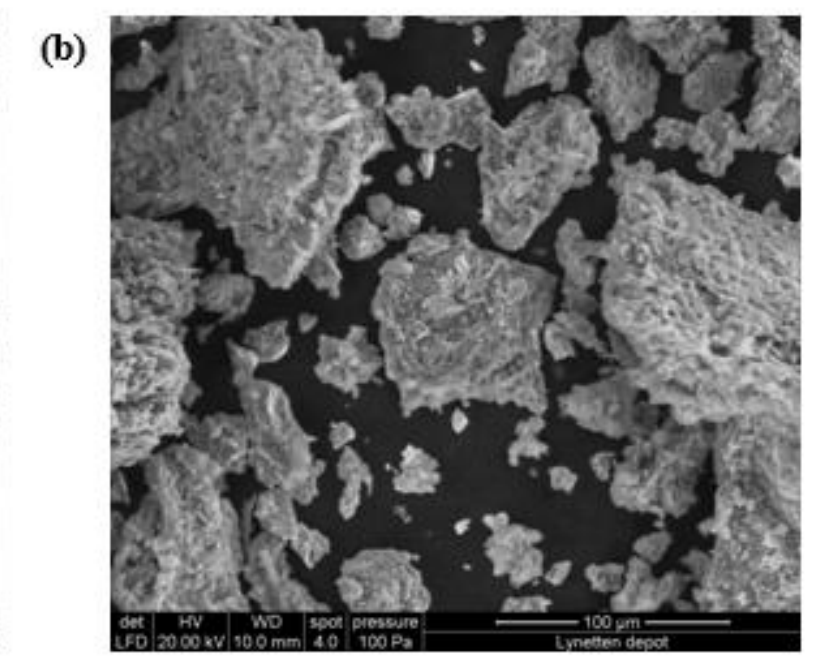

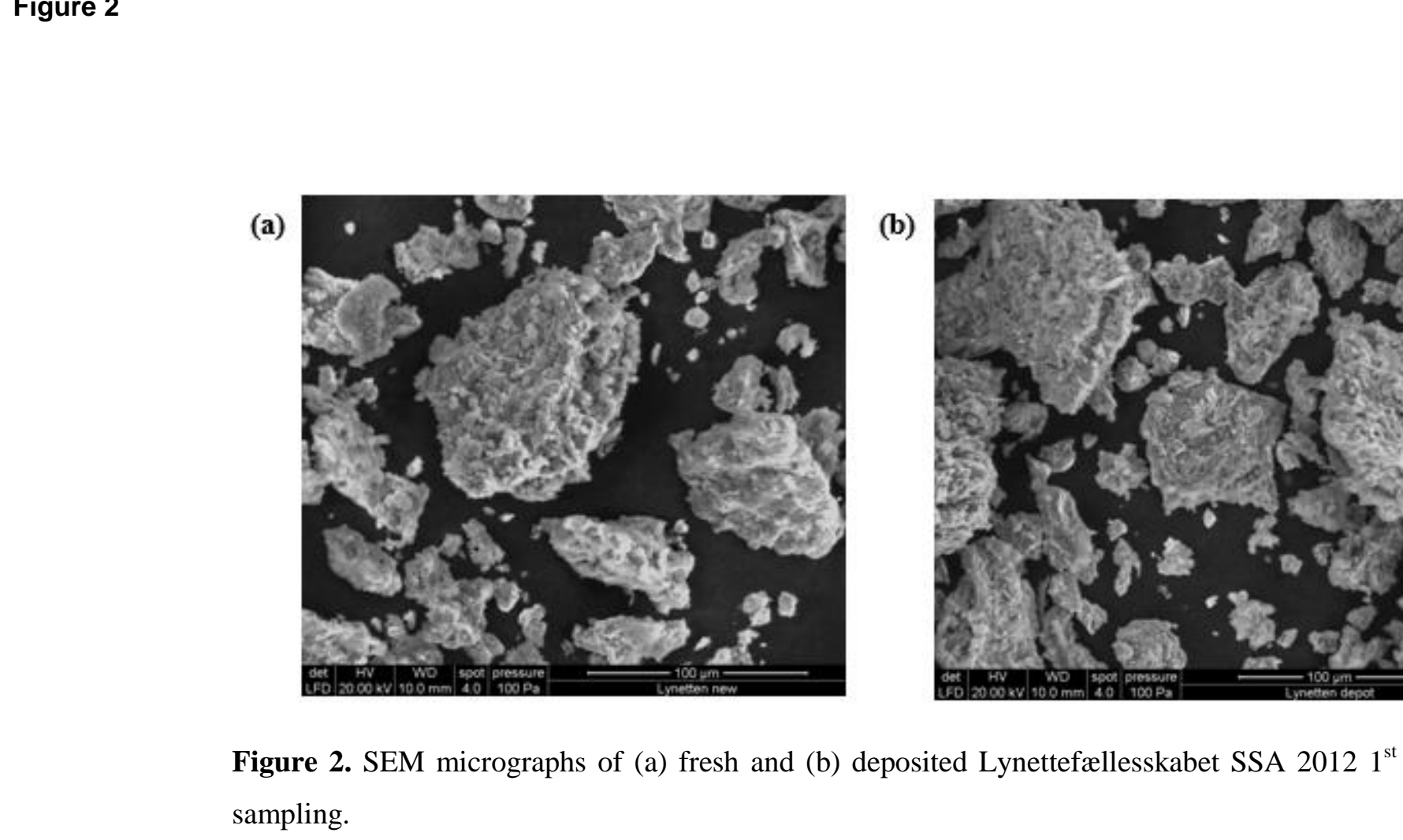

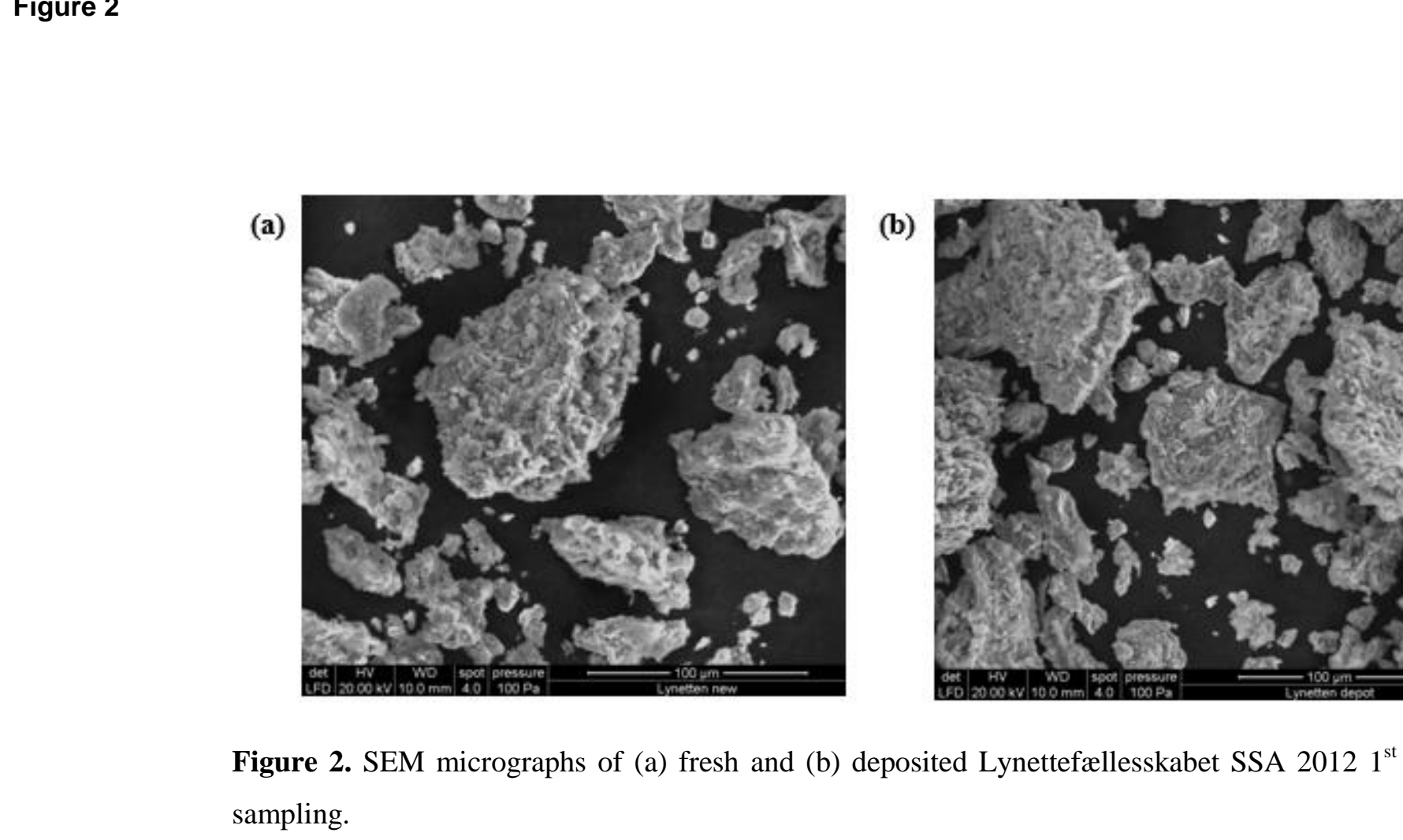
Figure 2

$$
\text { SEM micrographs of (a) fresh and (b) deposited Lynettefællesskabet SSA } 20121^{\text {st }}
$$

.

. 


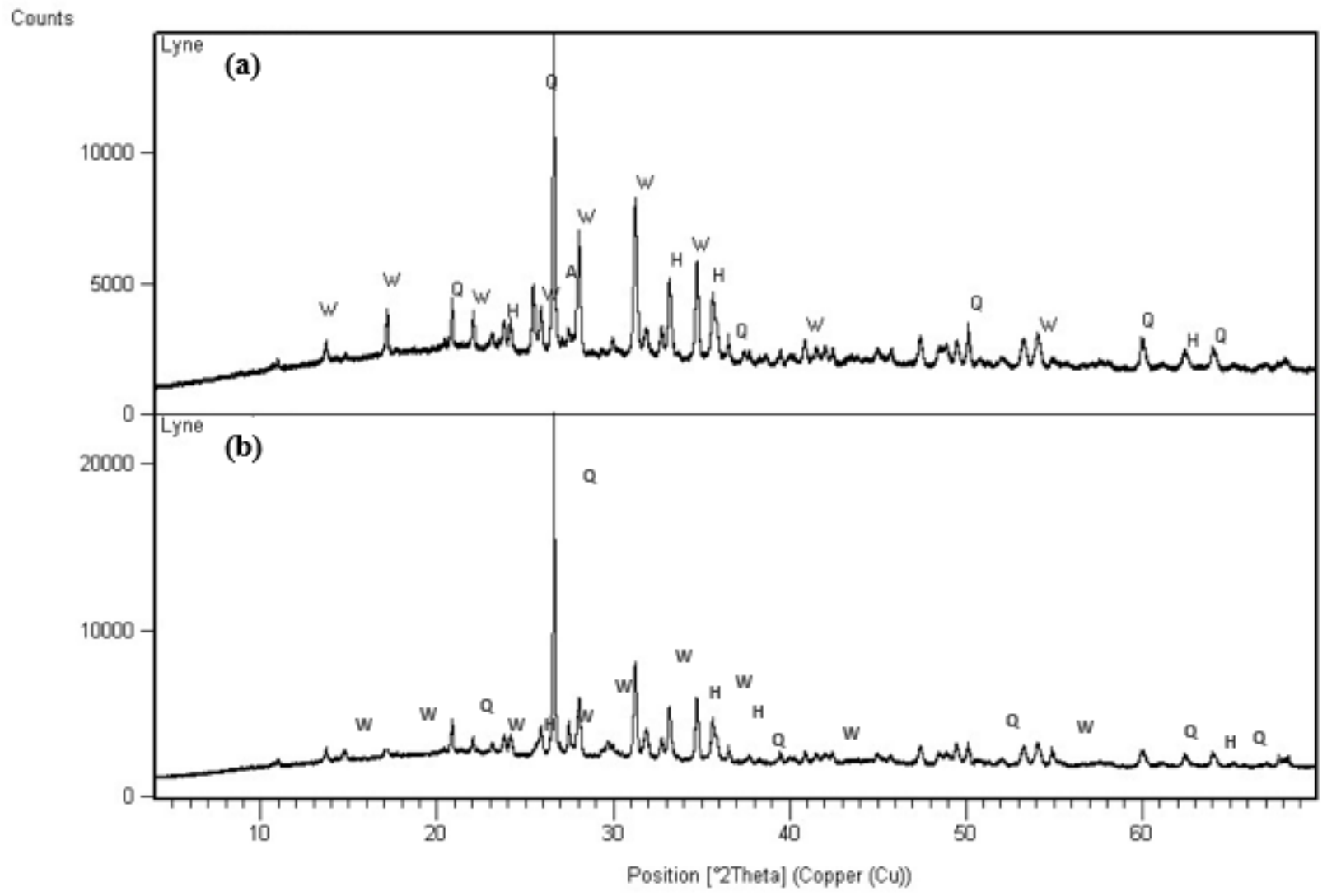

Figure 3. XRD diffractograms of (a) fresh and (b) deposited Lynettefællesskabet SSA $20121^{\text {st }}$ sampling (Q - Quartz, W- Whitlockite, H - Hematite, A - Anhydrite). 

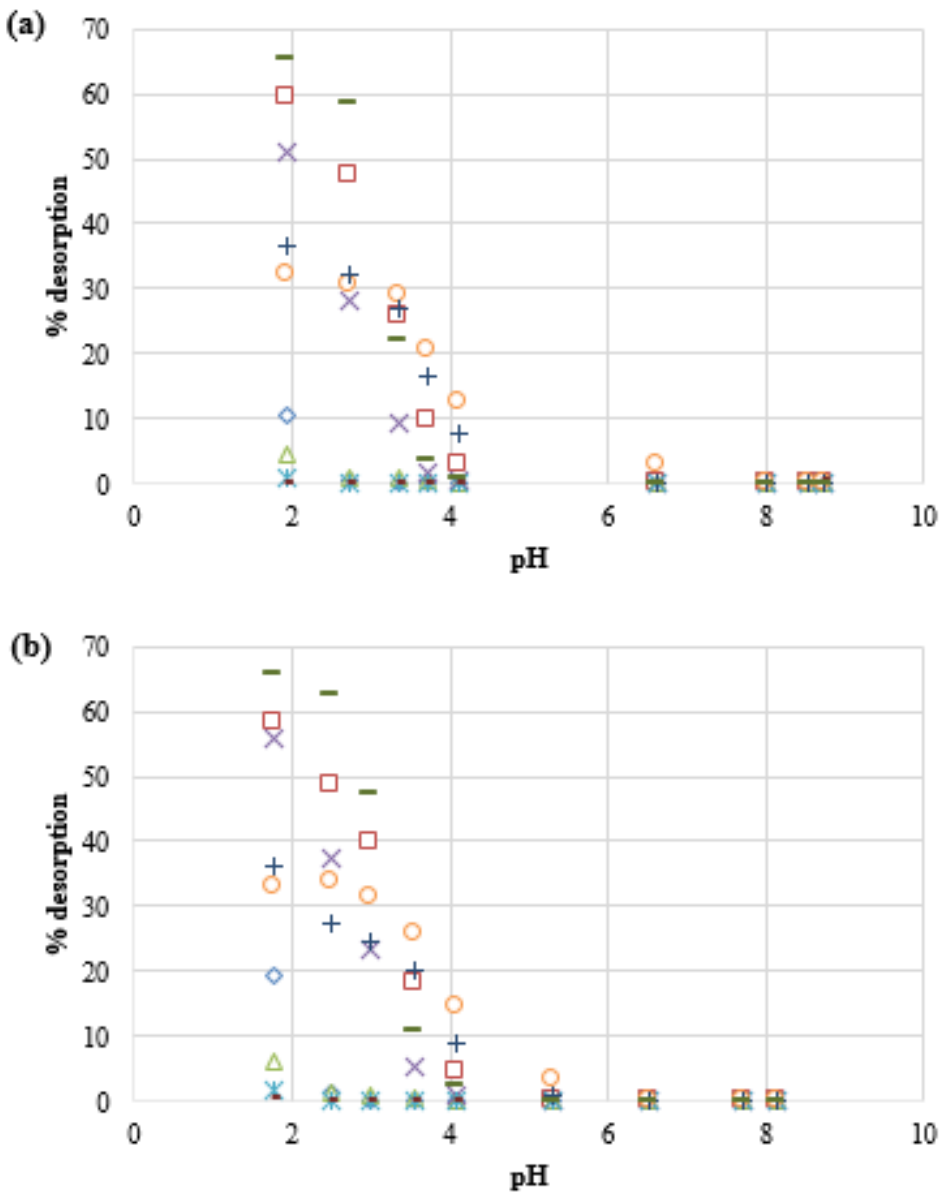

$\odot \mathrm{Al} \square \mathrm{Cd} \triangle \mathrm{Cr} \times \mathrm{Cu} \times \mathrm{Fe} \circ \mathrm{Ni}+\mathrm{P}-\mathrm{Pb}-\mathrm{Zn}$

Figure 4. Phosphorus and metal extraction as a function of $\mathrm{pH}$ in batch extraction experiments on (a) fresh and (b) deposited SSA Lynettefællesskabet $2012\left(1^{\text {st }}\right.$ sampling) using $\mathrm{HNO}_{3}$. 


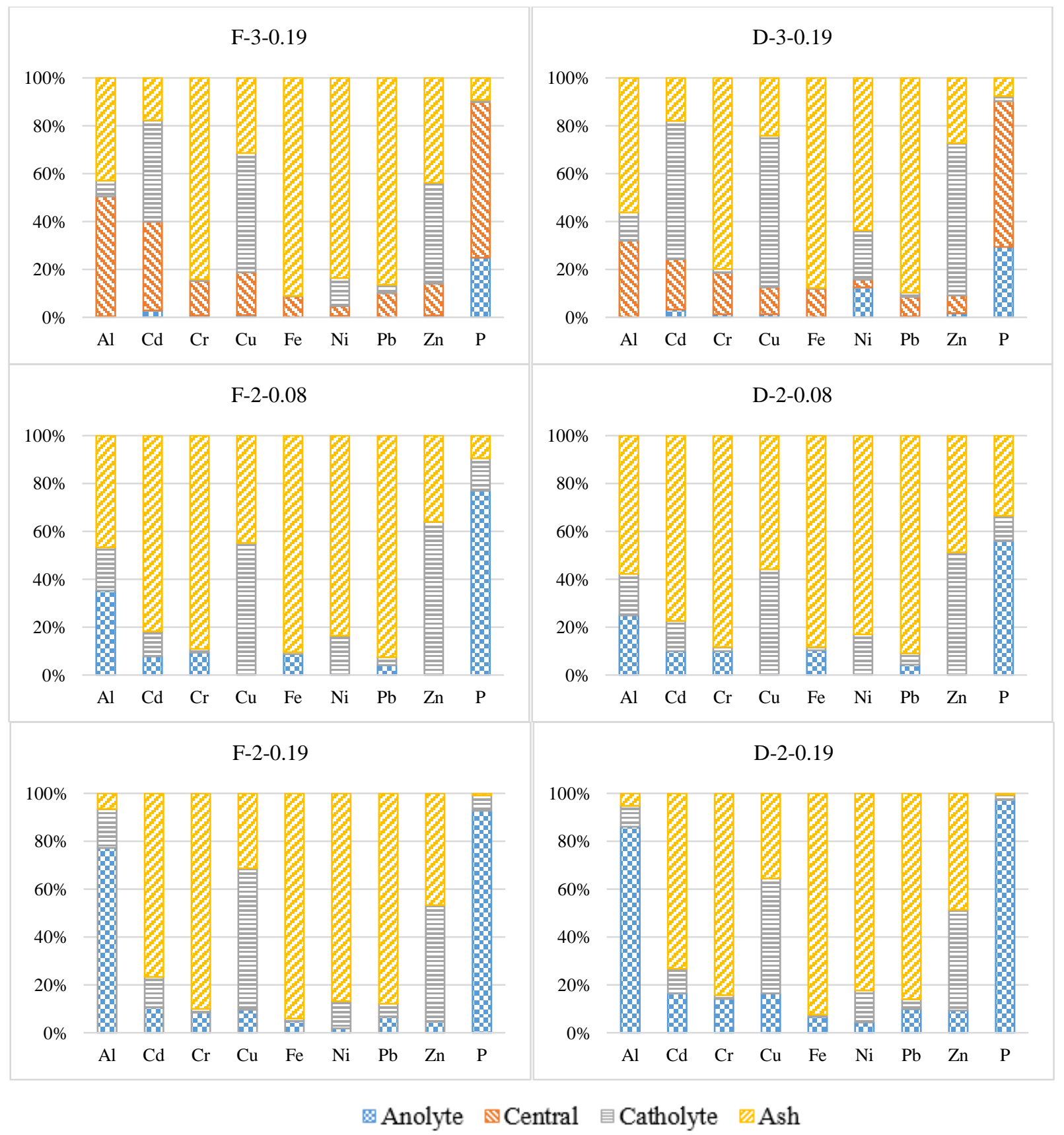

Figure 5. Percentage of heavy metals and phosphorus in the different matrices after the ED treatment in the $3 \mathrm{C}$ and $2 \mathrm{c}$-cell design. 
Table 1. Experimental design for the Lynettefællesskabet SSA $\left(2012,1^{\text {st }}\right.$ sampling).

\begin{tabular}{|c|c|c|c|c|}
\hline Experiment & Lynetten SSA sample & Cell design & SSA compartment & $\mathrm{H}_{2} \mathrm{SO}_{4}(\mathrm{M})$ \\
\hline F-3-0.19 & Fresh (2012) & \multirow{2}{*}{3 compartment } & \multirow{2}{*}{ central } & \multirow{2}{*}{0.19} \\
\hline D-3-0.19 & Deposited (2012) & & & \\
\hline F-2-0.08 & Fresh (2012) & \multirow{4}{*}{2 compartment } & \multirow{4}{*}{ anode } & \multirow{2}{*}{0.08} \\
\hline D-2-0.08 & Deposited (2012) & & & \\
\hline F-2-0.19 & Fresh (2012) & & & \multirow{2}{*}{0.19} \\
\hline D-2-0.19 & Deposited (2012) & & & \\
\hline
\end{tabular}


Table 2- Characteristics of the studied Danish SSA including heavy metal concentrations in relation to the total dry mass (mean \pm STD) and limiting values for spreading at agricultural land. Values reported in literature were also used for comparison.

\begin{tabular}{|c|c|c|c|c|c|c|c|c|c|c|c|}
\hline \multirow{3}{*}{\multicolumn{2}{|c|}{ Parameter }} & \multicolumn{6}{|c|}{ Lynettefallesskabet } & \multicolumn{2}{|c|}{ Avedore } & \multirow{3}{*}{$\begin{array}{l}\text { Limiting values } \\
\quad(\mathrm{mg} / \mathrm{kg})^{\mathrm{a}}\end{array}$} & \multirow{3}{*}{ Literature ${ }^{b}$} \\
\hline & & \multicolumn{2}{|c|}{$2012\left(1^{\text {st }}\right.$ sampling $)$} & \multicolumn{2}{|c|}{$2012\left(2^{\text {nd }}\right.$ sampling $)$} & \multicolumn{2}{|c|}{2013} & \multirow{2}{*}{$\begin{array}{c}2012 \\
\text { Fresh }\end{array}$} & \multirow{2}{*}{$\begin{array}{c}2014 \\
\text { Fresh }\end{array}$} & & \\
\hline & & Fresh $^{(1)}$ & Deposited $^{(1)}$ & Fresh & Deposited & Fresh & Deposited & & & & \\
\hline \multirow{5}{*}{ 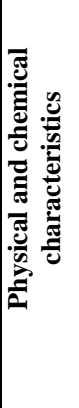 } & $\mathrm{pH}\left(\mathrm{H}_{2} \mathrm{O}\right)$ & $12.44 \pm 0.01 * \#$ & $8.85 \pm 0.03 *$ & $12.4 \pm 0.05 * \#$ & $8.3 \pm 0.03 *$ & $12.6 \pm 0.02 \#$ & $12.6 \pm 0.01 \#$ & $10.4 \pm 0.0 *$ & $9.6 \pm 0.10 *$ & & \\
\hline & Water content $(\%)$ & $0.10 \pm 0.18 *$ & $16 \pm 0.38 *$ & $0.09 \pm 0.03$ & $14.4 \pm 0.09$ & $3.70 \pm 0.04 \#$ & $3.93 \pm 0.07 \#$ & - & $0.16 \pm 0.01$ & & \\
\hline & Loss on ignition $\left(550^{\circ} \mathrm{C} ; \%\right)$ & $0.15 \pm 0.05 * \#$ & $0.92 \pm 0.08 *$ & $0.25 \pm 0.05$ *\# & $0.16 \pm 0.00 *$ & $2.58 \pm 0.01 *$ & $0.47 \pm 0.04 *$ & $0.3 \pm 0.1 * \#$ & $0.57 \pm 0.07 *$ & & \\
\hline & Solubility in water $(\%)$ & $1.8 \pm 0.1 *$ & $3.1 \pm 0.0 *$ & 5.12 & 0.84 & $5.3 \pm 0.0$ & $5.6 \pm 0.79$ & - & 29.5 & & \\
\hline & Gas production (mL gas/g) & $1.6 \pm 0.1$ & $1.9 \pm 0.2$ & - & - & - & - & - & - & & \\
\hline \multirow{9}{*}{ 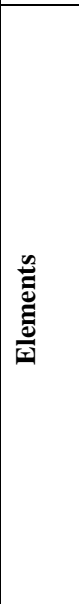 } & $\mathrm{P}(\mathrm{g} / \mathrm{kg})$ & $134 \pm 1$ & $130 \pm 5$ & $161 \pm 12$ & - & $72.5 \pm 0.01 *$ & $68.3 \pm 1.5 *$ & $112 \pm 2 \#$ & $105.4 \pm 3.8 \#$ & & $39-123$ \\
\hline & $\mathrm{Al}(\mathrm{g} / \mathrm{kg})$ & $22.6 \pm 0.5 *$ & $21.5 \pm 0.7 *$ & 21.2 & 19.5 & $14.2 \pm 0.0$ & - & $20.3 \pm 0.5 *$ & $22.1 \pm 0.6 *$ & & $19.7-218$ \\
\hline & $\mathrm{Fe}(\mathrm{g} / \mathrm{kg})$ & $60.0 \pm 1.4$ & $62.0 \pm 2.3$ & 44.0 & - & $36.3 \pm 0.1$ & - & $78.2 \pm 2.9 *$ & $53.2 \pm 1.5 *$ & & $47-200$ \\
\hline & $\mathrm{Zn}(\mathrm{mg} / \mathrm{kg})$ & $3335 \pm 77$ *\# & $3157 \pm 128 *$ & $3060 \pm 222 \#$ & $2810 \pm 117$ & $2414 \pm 10$ *\# & $2270 \pm 66.7 * \#$ & $2160 \pm 60$ *\# & $2410 \pm 72$ *\# & 4000 & $448-2737$ \\
\hline & $\mathrm{Cu}(\mathrm{mg} / \mathrm{kg})$ & $758 \pm 4.9 *$ & $733 \pm 9 *$ & $711 \pm 5.65 *$ & $694 \pm 6.49 *$ & $512 \pm 4 \#$ & $507 \pm 7.58 \#$ & $550 \pm 10 *$ & $815 \pm 18 *$ & 1000 & $417-690$ \\
\hline & $\mathrm{Pb}(\mathrm{mg} / \mathrm{kg})$ & $293 \pm 44 \#$ & $297 \pm 9$ & $102 \pm 2.15 \#$ & $99.5 \pm 1.08 \#$ & $102 \pm 2 \#$ & $98.8 \pm 5.44 \#$ & $90 \pm 1 \#$ & $253 \pm 181 \#$ & 120 & $18-158$ \\
\hline & $\mathrm{Cr}(\mathrm{mg} / \mathrm{kg})$ & $45.5 \pm 0.4 \#$ & $44.9 \pm 0.7 \#$ & $29.7 \pm 0.66$ & $28.6 \pm 0.61$ & $45.0 \pm 0.5 \#$ & $44.9 \pm 0.40 \#$ & $80 \pm 2 *$ & $47 \pm 1$ *\# & 100 & $102-136$ \\
\hline & $\mathrm{Cd}(\mathrm{mg} / \mathrm{kg})$ & $3.25 \pm 0.04 \#$ & $3.14 \pm 0.08$ & $2.21 \pm 0.05$ & $2.16 \pm 0.09 \#$ & $2.2 \pm 0.1 \#$ & $2.2 \pm 0.1 \#$ & $3.4 \pm 0.1 \#$ & $3.54 \pm 0.35 \#$ & 0.8 & $0.4-3.9$ \\
\hline & $\mathrm{Ni}(\mathrm{mg} / \mathrm{kg})$ & $54.6 \pm 0.6$ & $55.7 \pm 1.0$ & $35.2 \pm 0.72$ & $35.4 \pm 0.58$ & $38.9 \pm 0.6$ & $37.8 \pm 0.14$ & $60 \pm 1$ & $62 \pm 1.6$ & 30 & $50-93$ \\
\hline
\end{tabular}

\section{NOTES:}

* indicate statistically significant differences among pairs (columns with some colour) $(\mathrm{p}<0.05)$ - t-test

\# indicate the absence of statistically significant differences inside the group of non-deposited and deposited SSA (p < 0.05) - ANOVA

${ }^{a}$ Danish EPA (Miljøstyrelsen)

${ }^{b}[5,12,14,24,28]$

(1) samples used in the experiments aiming P-recovery (acid washing and ED process). 
Table 3. Parameters measured at the beginning and at the end of the electrodialytic experiments.

\begin{tabular}{|c|c|c|c|c|c|c|c|}
\hline \multirow{3}{*}{ Experiment } & & & \multicolumn{4}{|c|}{ SSA suspension ${ }^{1}$} & \multirow{3}{*}{$\begin{array}{c}\text { Mass loss } \\
(\%)\end{array}$} \\
\hline & \multicolumn{2}{|c|}{ Voltage drop (V) } & \multicolumn{2}{|c|}{ pH } & \multicolumn{2}{|c|}{ Cond. $(\mathrm{mS} / \mathrm{cm})$} & \\
\hline & Start & End & Start & End & Start & End & \\
\hline F-3-0.19 & 5.1 & 4.2 & 2.25 & 1.61 & 22.2 & 11.7 & 41 \\
\hline D-3-0.19 & 6.8 & 4.4 & 2.04 & 1.84 & 32.4 & 13.2 & 40 \\
\hline F-2-0.08 & 6.7 & 4.3 & 2.63 & 1.68 & 9.6 & 22.5 & 43 \\
\hline D-2-0.08 & 5.7 & 4.7 & 2.47 & 1.55 & 14.1 & 32.8 & 41 \\
\hline F-2-0.19 & 5.0 & 4.5 & 2.11 & 1.28 & 15.9 & 32.6 & 42 \\
\hline D-2-0.19 & 4.8 & 4.7 & 2.80 & 1.24 & 26.7 & 33.3 & 36 \\
\hline
\end{tabular}

${ }^{1}$ Central compartment in the 3 compartment cell and anode compartment in the 2 compartment cell 
Table 4. MINTEQ calculation of major species of phosphate ions (\%) for concentrations of elements in the the ash suspension liquid at the end of the treatments.

\begin{tabular}{|c|c|c|c|c|c|c|c|c|c|c|c|c|c|}
\hline & \multirow{2}{*}{$\begin{array}{l}\text { Experiments } \\
\text { Fe oxidation state }\end{array}$} & \multicolumn{2}{|c|}{ F-3-0.19 } & \multicolumn{2}{|c|}{ D-3-0.19 } & \multicolumn{2}{|c|}{ F-2-0.08 } & \multicolumn{2}{|c|}{ D-2-0.08 } & \multicolumn{2}{|c|}{ F-2-0.19 } & \multicolumn{2}{|c|}{ D-2-0.19 } \\
\hline & & $\mathrm{Fe}(\mathrm{II})$ & $\mathrm{Fe}(\mathrm{III})$ & $\mathrm{Fe}(\mathrm{II})$ & $\mathrm{Fe}(\mathrm{III})$ & $\mathrm{Fe}(\mathrm{II})$ & $\mathrm{Fe}(\mathrm{III})$ & $\mathrm{Fe}(\mathrm{II})$ & $\mathrm{Fe}(\mathrm{III})$ & $\mathrm{Fe}(\mathrm{II})$ & $\mathrm{Fe}(\mathrm{III})$ & $\mathrm{Fe}(\mathrm{II})$ & $\mathrm{Fe}(\mathrm{III})$ \\
\hline \multirow[t]{7}{*}{$\mathbf{P}$} & $\mathrm{H}_{2} \mathrm{PO}_{4}^{-}$ & 22.6 & 21.2 & 28.8 & 27.2 & 27.6 & 27.6 & 22.8 & 22.6 & 14.6 & 14.2 & 13.7 & 13.3 \\
\hline & $\mathrm{H}_{3} \mathrm{PO}_{4}$ & 55.3 & 51.4 & 42.3 & 39.8 & 57.4 & 57.1 & 67.2 & 66.6 & 73.7 & 71.6 & 76.5 & 74.2 \\
\hline & $\mathrm{AlHPO}_{4}^{+}$ & 4.62 & 4.28 & 7.73 & 7.28 & 4.50 & 4.44 & 2.29 & 2.23 & 1.73 & 1.68 & 1.39 & 1.34 \\
\hline & $\mathrm{Al}_{2} \mathrm{PO}_{4}^{+3}$ & 0.35 & 0.32 & 0.69 & 0.66 & 0.27 & 0.27 & 0.07 & 0.06 & 0.08 & 0.08 & 0.06 & 0.05 \\
\hline & $\mathrm{CaH}_{2} \mathrm{PO}_{4}^{+}$ & 4.48 & 4.17 & 5.77 & 5.43 & 5.96 & 5.92 & 3.17 & 5.92 & 3.71 & 3.62 & 2.84 & 2.76 \\
\hline & $\mathrm{FeH}_{2} \mathrm{PO}_{4}{ }^{2+}$ & 12.6 & 12.9 & 14.6 & 10.9 & 4.31 & 3.09 & 4.48 & 3.75 & 6.17 & 7.30 & 5.55 & 7.05 \\
\hline & $\mathrm{FeHPO}_{4}^{+}$ & - & - & - & 8.68 & - & - & - & 1.64 & - & 1.49 & - & 1.33 \\
\hline
\end{tabular}


Table 1. Mass of element removed to the anolyte per $\mathrm{kg}$ of ash at the end of the electrodialytic experiments $(\mathrm{mg} / \mathrm{kg})$.

\begin{tabular}{crrrrrr}
\hline Elements & F-3-0.19 & D-3-0.19 & F-2-0.08 & D-2-0.08 & F-2-0.19 & D-2-0.19 \\
\hline $\mathrm{P}$ & 33334.7 & 37879.6 & 102978.0 & 72153.4 & 124054.5 & 125420.4 \\
$\mathrm{Al}$ & 86.3 & 54.3 & 7957.8 & 5346.9 & 7148.3 & 9592.1 \\
$\mathrm{Cd}$ & 0.1 & 0.1 & 0.3 & 0.3 & 0.3 & 0.5 \\
$\mathrm{Cr}$ & 0.4 & 0.4 & 4.3 & 4.5 & 3.8 & 6.4 \\
$\mathrm{Cu}$ & 6.3 & 9.3 & 0.0 & 0.0 & 72.9 & 120.4 \\
$\mathrm{Fe}$ & 27.1 & 59.1 & 5246.1 & 6410.9 & 2867.8 & 4114.6 \\
$\mathrm{Ni}$ & 0.3 & 7.0 & 0.0 & 0.0 & 1.0 & 2.4 \\
$\mathrm{~Pb}$ & 0.1 & 0.9 & 12.0 & 13.0 & 19.5 & 29.1 \\
$\mathrm{Zn}$ & 24.3 & 53.3 & 0.0 & 1.1 & 155.8 & 291.7 \\
\hline
\end{tabular}

